\author{
Maša Plešković1, Branka Drljača Margić2 ${ }^{2}$, Tihana Kraš ${ }^{3}$ \\ 1 University of Zagreb, Faculty of Humanities and Social Sciences, 2,3University of Rijeka, Faculty \\ of Humanities and Social Sciences \\ mplesko@m.ffzg.hr,bdrljaca@ffri.uniri.hr, tkras@uniri.hr
}

\title{
Speakers' attitudes and perceptions in relation to the maintenance of the Fiuman dialect
}

\begin{abstract}
The paper presents the results of a study that aims to investigate Fiuman speakers' attitudes and perceptions in relation to the maintenance of the Fiuman dialect - the regional minority Romance language spoken in the Croatian city of Rijeka and its surroundings - with a particular focus on age, gender and education level, as individual factors that might determine the processes of language maintenance and shift. A questionnaire enquiring into these issues was distributed to Fiuman speakers of different ages, genders and education levels; the participants' language biographies and self-assessed proficiency in Fiuman were also examined by the questionnaire. The results show that age and, to a lesser extent, gender and education level predict Fiuman speakers' self-perceived engagement with, attitudes towards and perceptions of Fiuman maintenance. More precisely, it was shown that Fiuman speakers' self-perceived engagement with Fiuman maintenance and their positive attitudes towards it rise with age and education level. In addition, Fiuman speakers' positive perceptions of Fiuman maintenance efforts rise with age and are more characteristic of women than of men. The results provide an insight into the present-day status of the Fiuman dialect, as seen through its speakers' lenses, and indicate both language maintenance and language shift tendencies.
\end{abstract}

\section{Introduction}

The Fiuman dialect is a regional minority Romance language spoken in the Croatian city of Rijeka and its surroundings in today's dominantly Croatian language setting. It belongs to the eastern branch of the Venet(i)an family of Italian dialects, spoken mostly in the Italian region of Veneto. Fiuman differs from standard Italian at almost all levels of linguistic analysis (see e.g. Bratulić, Đurđulov, Blecich and Kraš 2015), but they are genetically related and mutually intelligible. Conversely, Croatian and Fiuman are structurally and genetically different and mutually unintelligible. 
Nowadays, speakers of Fiuman are mainly bilingual or multilingual speakers of Fiuman, standard Italian and standard Croatian or one of its substandard varieties (Badurina and Matešić 2008; Lukežić 2008). Standard Italian, albeit a minority language itself in Croatia, has a different relationship to Croatian than Fiuman. It is the official language of Italian minority institutions of Rijeka, and its position is much more stable. The maintenance of Fiuman thus depends on sustaining a diglossic relationship with both standard Italian and Croatian.

The present study taps into Fiuman speakers' attitudes and perceptions in relation to Fiuman maintenance in this triglossic situation, with a particular focus on speakers' age, gender and education level. The interplay of these variables has not been investigated in previous studies of Fiuman, nor has there been an attempt to examine their impact on speakers' attitudes and perceptions in relation to Fiuman maintenance. The paper does not address other factors that affect Fiuman maintenance, such as speakers' use of Fiuman (in terms of domains and frequency of use), motivation for its use, intergenerational language transmission, speakers' identity or institutional support, as these issues are dealt with in Plešković (2019), Plešković, Kraš and Drljača Margić (2019) and Plešković, Drljača Margić and Kraš (submitted). The interaction of age, gender, education level, language attitudes and perceptions in the maintenance of Fiuman is explored in a quantitative manner to provide a firm starting point for a deeper exploration of this phenomenon in future qualitative studies.

The structure of the paper is as follows. In Section 2, the phenomena of language maintenance and language shift are defined, and factors contributing to them are explained. More information about Fiuman and an overview of previous studies into its maintenance are given in Section 3. Section 4 is dedicated to the methodology and the results of the present study. The results are discussed in Section 5 and the conclusion is given in Section 6.

\section{Factors contributing to language maintenance and shift}

The term language maintenance (LM) is used to describe a situation in which a minority language, as Fiuman is, persists in some or all domains of life despite the presence of the dominant or majority language. On the other hand, more or less gradual abandonment of the minority language and its substitution with the dominant or majority language leads to language shift (LS) (Pauwels 2004). According to Pauwels (2016), factors determining the processes of LM or LS fall into three broad categories: individual characteristics (e.g. age, gender, educational background, social class, race/ethnicity, language attitudes), minority group characteristics (e.g. the number of minority language speakers, settlement patterns, linguistic/cultural similarity to the majority group) and majority group characteristics (e.g. attitudes towards the minority language/culture, the existence of laws/policies that support linguistic diversity). These factors do not operate independently, but interact in 
complex ways. Their interaction is somewhat different in different communities, as each community is specific, and the interplay of micro factors throughout the history influences the status and use of a language in a given moment (Šimičić and Bilić Meštrić 2018).

Although all three groups of characteristics determine the maintenance of the minority language, it primarily depends on the individuals, their choices and attitudes, whether they will abandon or maintain their minority language (Potowski 2013). As Giles and Johnson (1987: 69) point out, it is individuals' personal decisions (although highly socially motivated) that prompt communities to implement strategies and "make up their own minds whether to maintain their ethnic tongue or let it erode". The individual characteristics of particular importance for the present study are age, gender, education level and language attitudes.

Regarding age, it is fairly well known that in multilingual settings, especially amongst migrants, LS usually takes place within three generations (Fishman 2013). Pauwels (2016) states that there is widespread evidence that the second generation maintains the minority language less than the first generation and that its use further declines with the next one. As Soehl (2016) describes, the first generation mostly speaks their native language, even if they acquire some of the host-country language. The second generation usually fully acquires the majority language through schooling and has very limited competence in the ancestral minority language. The majority language becomes their dominant language.

The same rule applies with territorial minorities, such as Fiuman. Older speakers typically use the minority language to a greater extent than younger ones (Pauwels 2016). In it they see an important link to their past and a close bond with other community members. This is why older generations, by keeping the language active, are considered to be protectors of minority languages and cultures (Pauwels 2005; Phinney, Romero, Nava and Huang 2001). Adolescents are usually under peer pressure for linguistic and cultural conformity, and strive to assimilate into the majority community, where the use of the minority language can have the opposite effect of exclusion and stigmatisation (Lee 2002; Luo and Wiseman 2000; Potowski 2013; Zhang and Slaughter-Defoe 2009). By becoming part of the majority community and its educational and working environments, minority community members often shift to the majority language, neglecting the minority language or confining it to private and intimate settings. They spend more time with their friends and schoolmates, and tend to blend in rather than be with their family and relatives, where the minority language is nurtured. They use the minority language only for communication with the oldest generation, whose members are usually responsible for the transmission of the minority language to the youngest. Furthermore, the youngest speakers have not completely developed their identity yet, which is for many communities closely related to language as the main value (Komondourous and McEntee-Atalianis 2008; Smolicz 1980; Yağmur and Akinci 2003). Lee (2002) argues that to understand the true value of the minority lan- 
guage and grasp the benefits of multilingualism, some psychological maturation is necessary, and it often comes at a later age. Besides, the youngest speakers do not fully realise that knowing the minority language might also give them a competitive edge in terms of finding a job or professional advancement (Cho 2000; Lao 2004; Park and Sarkar 2007; Zhang and Slaughter-Defoe 2009) and help them learn new languages (Sofu 2009).

Gender tends to be a less clear-cut factor for predicting LM or LS than age. Women seem to be more likely to transmit the minority language to their children (Clyne and Kipp 1997; Romaine 1995), although there are some exceptions to this (Cavanaugh 2006; Jagodić 2011). They seem to encourage greater use of the minority language, and value its social and affective functions more positively (Holmes 1993; Winter and Pauwels 2005). In a number of traditional communities, where gender roles are more strictly determined, it is considered natural and inherent to women to take care of children and the household. Because for most minority families, their heritage language is spoken and culture practised within the home, it is also the main setting for language transmission (Plešković, Drljača Margić and Kraš, submitted). Particularly in the past, when women stayed at home, mothers, grandmothers and other female relatives were guardians of the minority tradition and language, and transmitted them to the children. Women's emancipation, however, greatly contributed to the abandonment of the minority language and the adoption of the majority one (Callan, Gallois and Forbes 1983).

It is important to mention that gender as a predictor of LM or LS usually depends on other factors, such as endogamous and exogamous marital practices, that is, marrying within the same linguistic group or into another one. Where both parents speak the same minority language and use it as a preferred means of communication in the family, LM is more likely. In contrast, the minority language is negatively affected by exogamy. In families where parents speak different languages (either different minority languages or the minority and the majority language), opportunities for LM must be created and both parents must have their role in it. However, it is primarily up to the minority language speaker, be it mother or father, to devote more effort to maintaining their language.

Similarly to gender, education level is also a less reliable predictor of LS or LM than age. Soehl (2016) observes that more educated parents may have more resources to transmit their language and homeland cultural practices to their children, which is consistent with Portes and Hao's (2002) and Portes and Rumbaut's (1996) claim that more educated families are more likely to be bilingual in the majority and the minority language. Nevertheless, more educated parents are also more likely to decide not to transmit or use the minority language to better integrate into the host society. However, those who do decide to transmit their language to their children are more likely to succeed in it than less educated parents, especially as far as developing full fluency and literacy is concerned (Soehl 2016). Along these lines, Sofu (2009) reports that young educated people can cherish their 
minority language as part of their multilingual repertoire and use it as a symbol of their distinctive cultural identity. However, not being exposed to the majority language through schooling and being to a certain extent excluded from the majority society can benefit LM, which is particularly evident among older speakers. For example, first-generation immigrants in Australia showed the lowest level of LS because of their limited proficiency in the majority language and limited exposure to it. Previous studies of Fiuman also showed similar tendencies (Crnić Novosel and Spicijarić Paškvan 2014, 2015; Plešković 2019).

Beyond individual characteristics, but related to educational level, institutional support, that is, an (in)formal representation that a language group gets in the various institutions of a nation, region or community (Giles, Bourhis and Taylor 1977), has an important role in LM because it enables speakers to see the usefulness of their language in a context other than family. The educational system, as a mechanism of institutional support to a language, can provide an opportunity for learning the minority language and promote its use among community members (Ehala 2009; Fishman 1991; Gorter and Cenoz 2012; Pauwels 2005). However, institutional support is not sufficiently effective for LM if speakers' attitudes towards LM are not favourable (Ehala 2009; Pauwels 2005; Yağmur 2004).

Turning to languages attitudes, communities whose members have positive attitudes towards their language as a symbol of group identity are much more likely to maintain it (Pauwels 2004). Parents' positive attitudes towards the minority language have positive effects on children's language proficiency (Guardado 2002; Lao 2004; Phinney, Romero, Nava and Huang 2001) and reinforce children's ethnic and cultural identity as minority members (Lee 2002; Sofu 2009; Zhang and Slaughter-Defoe 2009). Nevertheless, positive attitudes do not guarantee LM if there are no concrete actions and intergenerational language transmission. Also, favourable language attitudes do not necessarily result in language transmission, greater language proficiency or wider language use (Šimičić and Bilić Meštrić 2018). Conversely, negative attitudes do lead to LS (Potowski 2013; Zhang and Slaughter-Defoe 2009), that is, to the hampered intergenerational transmission, reduced language use, language simplification and reduction, and, consequently, to language abandonment (Šimičić and Bilić Meštrić 2018). Speakers' perceptions of their language status may also mobilise community actions to protect the minority language and secure its sustainability (Smith, Ehala and Giles 2017).

From what is said above, it is obvious that age, gender, education level and language attitudes are related to many other factors and that none of them can be taken as a sole predictor of LM or LS. As Pauwels (2016: 112) notes, studies conducted so far indicate that it is not easy to give a predictive model for LM or LS, but they contribute to an understanding of these issues in all their variety. Besides, the studies emphasise the dynamic character of all factors and the way they interact in different communities, especially in settings which are characterised by linguistic fluidity rather than stability (e.g. large cities). 


\section{The Fiuman dialect and its maintenance}

The origins of Fiuman are not known for certain. According to earlier studies (Batò 1999; G. Depoli 1999), Fiuman developed from the vernacular Latin spoken in the city area by the romanised Illyric tribes, but according to more recent studies (Bidwell 1967; Crnić Novosel and Spicijarić Paškvan 2014; Rošić 2002; Spicijarić Paškvan and Crnić Novosel 2014), it is more probable that it is a colonial Venetian dialect, which developed owing to the commercial activities of the Venetian merchants on the eastern Adriatic coast. In any event, there is evidence that Fiuman has been spoken as one of the two indigenous languages of the city of Rijeka (the other one being Chakavian) from the 15 th century onwards, or even earlier.

The official languages of Rijeka varied until the beginning of the 20th century as the city belonged to different states. After World War II, Rijeka became part of the Socialist Federal Republic of Yugoslavia, and Croatian (called hrvatskosrpski at the time) replaced Italian as the official language, which had this status in the city between the two world wars. Following this, around 30.000 Fiuman speakers left the city (Giuricin and Scotti 2006; Žerjavić 1993), while Slavic-speaking newcomers populated it (Crnić Novosel and Spicijarić Paškvan 2015). This adversely affected both the status of Fiuman as a prestigious urban dialect and the instrumental motivation for its use. It also led to a decrease in the number of its speakers. Today, Fiuman is spoken by a relatively small group of speakers in an otherwise dominant Croatian setting. Its speakers primarily use it to identify themselves as natives of ancient Rijeka and keep it as a symbol of belonging to the minority community.

No record of the current number of Fiuman speakers exists. This number cannot be established based on the information from the census because Fiuman is not listed as a mother tongue. However, because Fiuman speakers tend to declare themselves as members of the Italian national minority and as Italian mother tongue speakers, looking at these two census categories might give us some indications as to the number of Fiuman speakers. The census data for the city of Rijeka show that the number of Italian minority members has declined from 2,763 (1.92\%) to 2,445 (1.90\%) and of Italian mother tongue speakers from 2,745 (1.91\%) to 2,276 (1.77\%) between 2001 and 2011 (Croatian Bureau of Statistics 2001, 2011).

According to the Constitution of the Republic of Croatia (2014) and the Statute of the City of Rijeka (Statut Grada Rijeke 2016), the right to use the Italian language and script in the public domain and to organise and engage in educational and cultural activities is guaranteed to the Italian minority in Rijeka. In accordance with that, standard Italian is the medium of instruction in Italian minority nurseries and schools in Rijeka, and the official language of other Italian minority institutions in Rijeka, such as the Italian Community of Rijeka (It. Comunità degli Italiani di Fiume), the Italian National Theatre (It. Dramma Italiano), the EDIT publishing house and the La Voce del Popolo daily newspaper. There are also several editions of daily news in Italian on the local radio station, Radio Rijeka/Radio Fiume. To our knowledge, 
Fiuman is scarcely present in education and traditional media. Its use in social media, however, seems to be on the rise (Plešković 2019; Plešković, Kraš and Drljača Margić 2019). In addition, several texts in Fiuman written by Laura Marchig appeared on the Internet (see https://www.rijekadanas.com/?s=la+scartaza) in the column called La Scartaza in 2018 and 2019.

Until recently, the interest of scholars has been directed primarily towards the description of Fiuman grammar and vocabulary (Bató 1999; Berghoffer 1999; Bidwell 1967; Blecich and Tamaro 2015; Bratulić, Đurđulov, Blecich and Kraš 2015; A. Depoli 1913; G. Depoli 1999; Folena 1968-1970; Gottardi 2007; Lukežić 1993; Pafundi 2011; Rošić 2002; Samani 2007; Spicijarić Paškvan 2018). Lately, however, the focus has shifted to Fiuman maintenance, the studies yielding contradictory results. Lukežić (1993) and Rošić (2002) regard Fiuman endangered, while Crnić Novosel and Spicijarić Paškvan (2014, 2015) and Spicijarić Paškvan and Crnić Novosel (2014) argue that there is a tendency towards its maintenance as evidenced by intergenerational transmission and the existence of proficient young speakers. Plešković, Kraš and Drljača Margić (2019) and Plešković, Drljača Margić and Kraš (submitted) reveal both LM and LS tendencies, while Plešković (2019) finds more evidence for LS than LM.

Lukežić (1993: 37) argues that Fiuman "is vegetating" and "atrophying in oral communication of its last speakers" due to contact with two standards (Croatian and Italian) and because of the political, ideological and demographic changes in Rijeka after World War II. According to Lukežić (2008: 445), Fiuman is not "a dialect, spoken by the whole city population, but rather a sociolect, a means of communication for a specific social group". Rošić (2002: 17) also states that Fiuman is in decline and that its complete loss is inevitable because "it has a very small chance of continuing beyond the survival of its older speakers" (11) and because "the speech of younger generations has been greatly influenced by standard Italian language" (12). Neither study, however, provides any empirical evidence to support these claims.

On the basis of the results obtained via a questionnaire conducted among 107 Fiuman speakers, Crnić Novosel and Spicijarić Paškvan (2014, 2015) and Spicijarić Paškvan and Crnić Novosel (2014) state that Fiuman is an important symbol of identity for its speakers, who are inclined towards its preservation. Their findings suggest that although Fiuman is restricted to private domains, informal situations and oral communication, its speakers believe in its maintenance (although their number is in decline) and in the importance of their contribution through intergenerational transmission. In fact, Crnić Novosel and Spicijarić Paškvan (2014) report that $86 \%$ of speakers aged up to 35 years, and even a larger proportion of older speakers, use Fiuman daily. Drljača Margić, Kraš and Smiljanić (2015) state that Fiuman is also used in informal communication in the Italian minority educational and other institutions. 
Using a questionnaire administered to 244 Fiuman speakers, Plešković, Kraš and Drljača Margić (2019) show a decrease in the spoken use of Fiuman today in comparison to the past, but also an increase in its written use, especially among younger speakers. According to Fiuman speakers, there are numerous reasons for the decrease in spoken use, the main ones being the reduced number of speakers and demographic changes in the city. The current increase in written use relates primarily to communication via social networks, text messaging and e-mail, as well as to communication at work.

Despite growing trends in written use, Plešković (2019), on the basis of both quantitative and qualitative research encompassing 283 Fiuman speakers (249 of whom filled in a questionnaire and 34 of whom took part in a semi-structured interview), argues that LS has already started among Fiuman speakers. The findings indicate that Fiuman vitality relies more on intergenerational transmission and speakers' emotional attachment to the collective identity than on the use of Fiuman in different domains, institutional support and positive demographic trends. However, in spite of speakers' strong emotional attachment to Fiuman as part of their cultural heritage and identity, they increasingly opt for Croatian. Although intergenerational transmission seems to persist, the number of active speakers is decreasing and so is the use of Fiuman. The qualitative data analysis shows that an increased use of Croatian was mainly motivated by the historical changes in the 20th century, especially after the Second World War, which had an impact on speakers' attitudes towards Fiuman. Nowadays Fiuman is spoken in private domains, and in informal and sometimes formal situations within the Italian national minority institutions. Younger generations report lower Fiuman proficiency and less frequent use of Fiuman, and place more importance on being part of the dominant Croatian community.

Plešković, Drljača Margić and Kraš (submitted), focused on a subset of data obtained from 34 Fiuman speakers via a semi-structured interview and reported in Plešković (2019). Their findings confirm that determining the position of a language with regard to LM and LS is an arduous task and rarely indicates only one of the two processes. The findings reveal that Fiuman speakers are aware of the importance of intergenerational transmission of their dialect, identify with it and want it to persist. Nevertheless, they report a decrease in language use as well as insufficient institutional and media support.

Previous studies did not take a closer look into the mutual interdependence of individual factors and speakers' stance on Fiuman maintenance. This study aims to fill this gap by examining Fiuman speakers' age, gender and education level in relation to their attitudes and perceptions regarding Fiuman maintenance. 


\section{The study}

\subsection{Aim and research questions}

The study aimed to determine whether Fiuman speakers' attitudes and perceptions in relation to Fiuman maintenance can be predicted from their age, gender and education level. The following research questions were posed:

1. Do age, gender and education level predict Fiuman speakers' self-perceived engagement with Fiuman maintenance?

2. Do age, gender and education level predict Fiuman speakers' attitudes towards and perceptions of Fiuman maintenance?

\subsection{Participants}

The sample comprised 249 Fiuman speakers aged from 14 to 90 years $(\mathrm{M}=47.94 ; \mathrm{SD}=1.40)$. The distribution of participants according to gender and education level is shown in Table 1.

\begin{tabular}{|c|c|c|c|c|c|c|c|}
\hline & \multicolumn{5}{|c|}{ Education } & \multirow[b]{2}{*}{ Total } \\
\hline & & $\begin{array}{c}\text { Primary } \\
\text { school }\end{array}$ & $\begin{array}{c}\text { Secondary } \\
\text { school }\end{array}$ & $\begin{array}{c}\text { Bachelor's } \\
\text { degree }\end{array}$ & $\begin{array}{c}\text { Master's } \\
\text { degree }\end{array}$ & $\begin{array}{c}\text { Doctoral } \\
\text { degree }\end{array}$ & \\
\hline \multirow[b]{2}{*}{ Gender } & Male & $\begin{array}{l}16 \\
(21.33 \%)\end{array}$ & $\begin{array}{l}29 \\
(38.67 \%)\end{array}$ & $\begin{array}{l}8 \\
(10.67 \%)\end{array}$ & $\begin{array}{l}19 \\
(25.33 \%)\end{array}$ & $\begin{array}{l}3 \\
(4 \%) \\
\end{array}$ & $\begin{array}{l}75 \\
(30.12 \%)\end{array}$ \\
\hline & Female & $\begin{array}{l}29 \\
(16.67 \%)\end{array}$ & $\begin{array}{l}66 \\
(37.93 \%)\end{array}$ & $\begin{array}{l}27 \\
(15.52 \%)\end{array}$ & $\begin{array}{l}47 \\
(27.01 \%)\end{array}$ & $\begin{array}{l}5 \\
(2.5 \%)\end{array}$ & $\begin{array}{l}174 \\
(69.88 \%)\end{array}$ \\
\hline \multicolumn{2}{|l|}{ Total } & $\begin{array}{l}45 \\
(18.07 \%)\end{array}$ & $\begin{array}{l}95 \\
(38.15 \%)\end{array}$ & $\begin{array}{l}35 \\
(14.06 \%)\end{array}$ & $\begin{array}{l}66 \\
(26.51 \%) \\
\end{array}$ & $\begin{array}{l}8 \\
(3.21 \%)\end{array}$ & 249 \\
\hline
\end{tabular}

Table 1. Distribution of participants according to gender and education level

It can be seen that female participants outnumbered male ones and that the majority of the participants completed secondary education, followed by the participants who obtained a master's degree. The lowest number of participants was awarded a doctoral degree.

The distribution of participants' age according to gender and education level is shown in Table 2.

\begin{tabular}{|c|c|c|c|c|c|c|c|c|c|c|c|c|}
\hline & \multicolumn{10}{|c|}{ Education } & \multirow{2}{*}{\multicolumn{2}{|c|}{ Total }} \\
\hline & \multicolumn{2}{|c|}{$\begin{array}{c}\text { Primary } \\
\text { school }\end{array}$} & \multicolumn{2}{|c|}{$\begin{array}{c}\text { Secondary } \\
\text { school }\end{array}$} & \multicolumn{2}{|c|}{$\begin{array}{c}\text { Bachelor's } \\
\text { degree }\end{array}$} & \multicolumn{2}{|c|}{$\begin{array}{c}\text { Master's } \\
\text { degree }\end{array}$} & \multicolumn{2}{|c|}{$\begin{array}{c}\text { Doctoral } \\
\text { degree }\end{array}$} & & \\
\hline & M & SD & $\mathrm{M}$ & SD & M & SD & M & SD & $\mathrm{M}$ & SD & M & SD \\
\hline Male & 40.49 & 29.51 & 52.38 & 20.47 & 42.00 & 22.85 & 38.21 & 18.99 & 47.67 & 8.39 & 47.37 & 22.27 \\
\hline Female & 34.14 & 27.16 & 53.06 & 22.88 & 54.48 & 19.88 & 45.89 & 14.71 & 52.6 & 8.68 & 48.18 & 22.02 \\
\hline
\end{tabular}

Table 2. Distribution of participants' age according to gender and education level 
The table shows that the male participants were on average somewhat younger than the female ones. It can also be seen that the youngest participants were found among those who received primary education, while the oldest were found among those who had secondary education.

The majority of the participants (95\%) were born and lived in Rijeka and its surroundings. They all reported to be Fiuman speakers. Most of them spoke standard Croatian or one of its dialectal varieties, standard Italian and one or more foreign languages in addition to Fiuman. A total of 223 participants (90\%) reported being exposed to Fiuman from birth and 172 participants (69\%) declared Fiuman, alone or in combination with other idioms, to be their mother tongue. Mean values of the participants' self-ratings of their proficiency in Fiuman, according to language skills, are given in Table 3.

\begin{tabular}{|l|l|l|l|l|l|l|l|l|}
\hline \multicolumn{8}{|c|}{ Language skills } \\
\hline \multicolumn{2}{|c|}{ Listening } & \multicolumn{3}{c|}{ Reading } & \multicolumn{2}{c|}{ Speaking } & \multicolumn{2}{c|}{ Writing } \\
\hline M & SD & M & SD & M & SD & M & SD \\
\hline 4.67 & 0.593 & 4.39 & 0.817 & 4.33 & 0.982 & 3.92 & 1.142 \\
\hline
\end{tabular}

Table 3. Participants' self-ratings of their proficiency in Fiuman according to language skills

We can see that the participants self-rated their proficiency in Fiuman rather highly ( 5 was the highest and 1 the lowest rating, see below). Listening was rated the highest and writing the lowest.

\subsection{Materials}

The questionnaire, which is an adapted part of the Fiuman Dialect Questionnaire (Upitnik o fijumanskom dijalektu, Bratulić, Drljača Margić and Kraš 2017), elicited the participants' sociodemographic data (age, gender, education level, former and current residence) and explored their language biography, proficiency in Fiuman, engagement with, attitudes towards and perceptions of Fiuman maintenance. The participants self-assessed their proficiency in Fiuman on a five-point Likert scale for each language skill (listening, reading, speaking and writing) separately; the values on the scale were 1 ("none"), 2 ("elementary"), 3 ("good"), 4 ("very good") and 5 ("excellent"). The speakers' self-perceived engagement with Fiuman maintenance was explored via four statements followed by a five-point Likert scale ranging from 1 ("It does not apply to me at all") to 5 ("It fully applies to me"). The participants' attitudes towards and perceptions of Fiuman maintenance were explored through 19 statements accompanied by a five-point Likert scale ranging from 1 ("I completely disagree") to 5 ("I completely agree").

The questionnaire was offered to participants in Croatian and Italian. Twentytwo participants completed it in Croatian and 227 in Italian. The participants were 
recruited in different ways, but predominantly via snowball sampling1. They completed the questionnaire on paper.

\subsection{Results}

\subsubsection{Preliminary analysis}

A principal component analysis (PCA) was applied to the four statements about speakers' self-perceived engagement with Fiuman maintenance ("I like hearing Fiuman", "I take every opportunity to speak Fiuman", "I participate in the Italian Community of Rijeka activities" and "I (will/would) transfer Fiuman to my children"). The Kaiser-Meyer-Olkin measure verified the sampling adequacy for the analysis $(\mathrm{KMO}=.70)$. The internal consistency of the dimension proved to be good, with a Cronbach's alpha of .71.

A PCA of the 19 statements about speakers' attitudes towards and perceptions of Fiuman maintenance was also conducted revealing three dimensions with a satisfactory internal consistency. The Kaiser-Meyer-Olkin (KMO) measure verified the sampling adequacy for the analysis ( $\mathrm{KMO}=.87)$.The first dimension concerned speakers' attitudes towards Fiuman maintenance comprising nine statements ("Fiuman is an important part of Fiuman speakers' identity", "Fiuman is an important part of Rijeka's Italian minority identity", "Fiuman is an important part of Rijeka's cultural heritage", "It is important to preserve Fiuman", "Parents should speak Fiuman with their children", "Activities in Fiuman should exist in all Italian minority nurseries in Rijeka", "Activities in Fiuman should exist in all Italian minority schools in Rijeka", "Fiuman should exist as an elective subject in all Italian minority schools in Rijeka", "Fiuman should exist as a compulsory subject in all Italian minority schools in Rijeka”). The second dimension concerned speakers' perceptions of Fiuman maintenance efforts embracing five statements ("Fiuman is being transmitted to new generations", "Fiuman speakers contribute to Fiuman maintenance", "The Italian Community of Rijeka is putting enough effort in Fiuman maintenance", "The city administration is putting enough effort in Fiuman maintenance", "In Rijeka there is interest in Fiuman maintenance"). The third dimension concerned speakers' perceptions of Fiuman endangerment containing three statements ("Fiuman is endangered", "Fiuman will disappear from use in the future", "Fiuman will be spoken in Rijeka in the future"2). Cronbach's alpha values of the three dimensions were $.88, .69$ and .64 respectively. Note that two of the original 19 items ("The efforts to preserve Fiuman are a waste of time", "If you do not speak the Fiuman dialect, you are not Fiuman") were eliminated due to their extremely low saturation, thereby increasing the factors' internal consistency. Four PCA factor scores were calculated as linear combinations of scores for each of the questionnaire's dimension.

1 Although aware that snowball sampling is not an ideal way of recruiting participants as the resulting sample is not random and may be somewhat biased, we resorted to it due to practical constraints.

This statement was recoded in the PCA, so the whole dimension assumed a negative meaning. 


\subsubsection{Main analysis}

To answer the research questions, four linear regression analyses were performed on the subscale results pertaining to speakers' self-perceived engagement with Fiuman maintenance (Engagement), speakers' attitudes towards Fiuman maintenance (Attitudes), speakers' perceptions of Fiuman maintenance efforts (Efforts) and speakers' perceptions of Fiuman endangerment (Endangerment) as criterion variables, and age, education level and gender as predictors. Age and education level (expressed in the number of years of education completed based on the education level obtained by a participant) were considered as continuous variables whereas gender was a dichotomous, categorical variable. Descriptives and intercorrelations between the linear regression variables are reported in Table 4.

\begin{tabular}{|l|l|l|l|l|l|l|l|l|}
\hline Variables & $\mathbf{M}(\mathrm{SD})$ & $\begin{array}{c}\text { En- } \\
\text { gage- } \\
\text { ment }\end{array}$ & $\begin{array}{l}\text { Atti- } \\
\text { tudes }\end{array}$ & Efforts & $\begin{array}{c}\text { Endanger- } \\
\text { ment }\end{array}$ & Age & $\begin{array}{l}\text { Educati- } \\
\text { on level }\end{array}$ & Gender \\
\hline $\begin{array}{l}\text { Engage- } \\
\text { ment }\end{array}$ & $\begin{array}{l}4.03 \\
(0.86)\end{array}$ & - & & & & & & \\
\hline Attitudes & $\begin{array}{l}4.47 \\
(0.58)\end{array}$ & $.67^{* *}$ & - & & & & & \\
\hline Efforts & $\begin{array}{l}3.23 \\
(0.72)\end{array}$ & $.33^{* *}$ & $.34^{* *}$ & - & & & & \\
\hline $\begin{array}{l}\text { Endanger- } \\
\text { ment }\end{array}$ & $\begin{array}{l}3.35 \\
(0.53)\end{array}$ & $-.16^{*}$ & $.21^{* *}$ & .30 & - & & & \\
\hline Age & $\begin{array}{l}47.94 \\
(22.06)\end{array}$ & $.50^{* *}$ & $.41^{* *}$ & $.39^{* *}$ & -.08 & - & & \\
\hline $\begin{array}{l}\text { Education } \\
\text { level }\end{array}$ & $\begin{array}{l}13.28 \\
(3.35)\end{array}$ & $.20^{* *}$ & $.24^{* *}$ & $-.19^{*}$ & -.11 & .11 & - & \\
\hline Gender & - & .08 & .11 & .08 & -.02 & .02 & .05 & - \\
\hline
\end{tabular}

${ }^{*} p<.05 ;{ }^{* *} p<.01$

Table 4. Descriptives and bivariate correlations between the criterion variables (PCA factor scores) and predictors (age, education level and gender)

The descriptive data for the dimensions' composite scores show that the highest agreement was found for Attitudes, whereas the lowest was found for Efforts. The bivariate correlational data show that Engagement showed a moderately strong and a moderate positive correlation with Attitudes $(r=.67, p<.01)$ and Efforts $(r=.33, p<.01)$ respectively, while it showed a weak negative correlation with Endangerment $(r=-.16, p<.01)$. This suggests a considerable increase in speakers' self-perceived engagement with Fiuman maintenance together with an increase in their positive attitudes towards Fiuman maintenance. Furthermore, with a somewhat moderate increase in speakers' self-perceived engagement with Fiu- 
man maintenance, their positive perceptions of Fiuman maintenance efforts also seem to increase. In additon, it seems that as speakers' self-perceived engagement with Fiuman maintenance increases, their perception of Fiuman as an endangered language slightly decreases, that is, they become slightly less pessimistic towards the prospects of its maintenance. Attitudes showed a moderately positive and a weaker positive correlation with Efforts $(r=.34, p<.001)$ and Endangerment $(r=.21$, $p<.001)$ respectively, suggesting that as speakers' positive attitudes towards Fiuman maintenance increase, their positive perceptions of Fiuman maintenance efforts also increase as well as their perception of Fiuman as an endangered language, that is, their pessimism towards the prospects of its maintenance.

Age showed a moderately strong positive correlation with Engagement $(r=.50$, $p<.01)$ and a moderate positive correlation with Attitudes $(r=.41, p<.01)$ and Efforts $(r=.39, p<.01)$. This indicates that with an increase in speakers' age, there is a moderately strong increase in their self-perceived engagement with Fiuman maintenance and a moderate increase in their positive attitudes towards Fiuman maintenance and positive perceptions of Fiuman maintenance efforts.

Education level showed a much lower positive correlation with Engagement $(r=.24, p<.01)$ and Attitudes $(r=.24, p<.01)$ and a rather low negative correlation with Efforts $(r=-.19, p<.05)$. This suggests that with an increase in speakers' education level, their self-perceived engagement with Fiuman maintenance and positive attitudes towards Fiuman maintenance slightly increase, while their positive perceptions of Fiuman maintenance efforts slightly decrease.

Gender showed no significant correlations with any of the factor scores' dimensions.

Turning to the results of the four linear regression analyses, the significant predictors' contribution to the variance explanation for the criterion variables is shown in Table 5.

\begin{tabular}{|l|l|c|c|c|}
\hline \multicolumn{1}{|c|}{$\begin{array}{c}\text { Criterion } \\
\text { variables }\end{array}$} & \multicolumn{1}{|c|}{ Predictors } & $\beta$ & $R$ & $R 2$ \\
\hline Engagement & Age & $\begin{array}{l}.48^{* *} \\
.14^{*}\end{array}$ & $.52^{* *}$ & $.27^{* *}$ \\
\hline Edtitudes & Age & $.46^{* *}$ & $.50^{* *}$ & $.25^{* *}$ \\
& Education level & $.13^{*}$ & & \\
\hline Efforts & Age & $.41^{* *}$ & $.44^{* *}$ & $.19^{* *}$ \\
& Gender ${ }^{*}$ & $.15^{*}$ & & \\
\hline
\end{tabular}

${ }^{*} p<.05 ;{ }^{* *}<.01$

1 Men were coded as 0 and women as 1 in the analysis.

Table 5. Summarised linear regression analyses results: Engagement, Attitudes and Efforts regressed on age, education level and gender 
The first linear regression analysis was calculated to predict Engagement based on age, education level and gender. A significant regression equation was found $(F(3,245)=30.83, p<.001)$, with a $R 2$ of .27 ( $27 \%$ of the explained variance of the criterion), with only age $(\beta=.48, t(245)=8.83, p<.001)$ and education level $(\beta=.14$, $t(245)=2.54 p<.05)$ bearing significance. The positive betas $(\beta)$ suggest a positive association between the criterion variable and the two predictors, that is, an increase in speakers' self-perceived engagement with Fiuman maintenance complemented by an increase in their age and education level.

The second linear regression analysis aimed to predict Attitudes based on age, education level and gender. The result was again significant $(F(3,245)=26.61, p<$ .001 ), with a $R 2$ of .25 ( $25 \%$ of the explained variance of the criterion), with only age $(\beta=.46, t(245)=8.19, p<.001)$ and education level $(\beta=.13, t(245)=2.32, p<.05)$ being significant. The positive betas $(\beta)$ between the criterion variable and the two predictors suggest an increase in speakers' positive attitudes towards Fiuman maintenance with an increase in their age and education level.

The third linear regression analysis, aiming to predict Efforts based on age, education level and gender, revealed yet another significant regression equation $(F(3,245)=19.61, p<.001)$, with a $R 2$ of $.19(19 \%$ of the explained variance of the criterion), with age $(\beta=.41, t(245)=7.17, p<.001)$ and gender $(\beta=.15, t(245)=2.63$, $p<.05)$ being significant. The positive betas $(\beta)$ suggest that there is an increase in speakers' positive perceptions of Fiuman maintenance efforts with an increase in their age and that women have more positive perceptions of Fiuman maintenance efforts than men.

The fourth linear regression analysis, which aimed to predict Endangerment based on age, education level and gender did not yield any statistically significant results.

Age seems to be the strongest predictor for three of the four criterion variables, namely Engagement, Attitudes and Efforts, affecting them significantly $(p<.001)$. Education level proved to be a much weaker yet significant predictor $(p<.05)$ for Engagement and Attitudes. Finally, gender was found to be a much weaker yet significant predictor $(p<.05)$ for Efforts.

Summarising the results of the regression analyses, age and, to a lesser extent, education level were found to predict Fiuman speakers' self-perceived engagement with and their attitudes towards Fiuman maintenance. Age and gender were also found to be predictors of Fiuman speakers' perceptions of Fiuman maintenance efforts, the former being a stronger predictor than the latter. None of the three variables - age, education level and gender - were found to predict Fiuman speakers' perceptions of Fiuman endangerment. 


\section{Discussion}

In an attempt to broaden our understanding of the present-day status of the Fiuman dialect in the city of Rijeka, we investigated Fiuman speakers' self-perceived engagement with, attitudes towards and perceptions of Fiuman maintenance, and explored the relationship between speakers' attitudes and perceptions and their age, gender and education level.

The descriptive results show that speakers perceive their engagement with Fiuman maintenance to be relatively high, through enjoyment they feel when exposed to Fiuman, communication in Fiuman whenever circumstances allow, participation in the Italian Community of Rijeka activities and the transmission of the dialect to their offspring. Their attitudes towards Fiuman maintenance are positive. Speakers regard the preservation of Fiuman to be of great importance, as it represents an important part of Fiuman speakers' identity, Rijeka's Italian minority identity and Rijeka's cultural heritage. They also believe that parents should speak Fiuman with their children, and that Fiuman should be present in Italian minority nurseries and schools in Rijeka through extracurricular activities and elective subjects. The respondents' perceptions are rather positive regarding Fiuman maintenance efforts, in the form of Fiuman speakers' intergenerational transmission of the dialect and contribution to its maintenance, the efforts expended by the Italian Community of Rijeka and the city administration, and interest in Fiuman maintenance that exists in Rijeka. However, they are more inclined to ascribe LM efforts and success to themselves than to other Fiuman speakers and broader community. In other words, they have more faith and are more optimistic about their own feelings, decisions and actions concerning Fiuman maintenance than those of other speakers and the relevant institutions. As for their perceptions of Fiuman endangerment, they nevertheless deem Fiuman to be endangered and are doubtful whether it will continue to be spoken in Rijeka.

As regards the association between the different dimensions of speakers' attitudes and perceptions investigated by the questionnaire, an increase in speakers' self-perceived engagement with Fiuman maintenance is accompanied by an increase in their favourable attitudes towards it and, to a lesser extent, a rise in their positive perceptions of Fiuman maintenance efforts. It is also accompanied by a decrease in their perception of Fiuman as an endangered language, that is, by an increase in their optimism about the prospects of its maintenance. Similarly, as speakers' positive attitudes towards Fiuman maintenance increase, their positive perceptions of Fiuman maintenance efforts also increase. However, speakers' perception of Fiuman as an endangered language, that is, their pessimism about the prospects of its maintenance, increases with a rise in their positive attitudes towards Fiuman maintenance. The perception of Fiuman as an endangered language is thus in a different relationship with speakers' self-perceived engagement with Fiuman maintenance and their attitudes towards it: speakers perceive Fiuman as 
an endangered language less as they engage more in its maintenance, but more as they have more positive attitudes towards Fiuman maintenance.

With respect to the association between age, gender and education level and the different dimensions of speakers' attitudes and perceptions, the results show that an increase in age corresponds to an increase in speakers' self-perceived engagement with Fiuman maintenance. It also corresponds, albeit to a lesser extent, to an increase in their positive attitudes towards Fiuman maintenance and their positive perceptions of Fiuman maintenance efforts. Similarly, a rise in education level is followed by a rise in speakers' self-perceived engagement with Fiuman maintenance and their positive attitudes towards it. Conversely, a growth in education level corresponds to a (slight) decline in speakers' positive perceptions of Fiuman maintenance efforts. Gender does not show any associations with different dimensions of speakers' attitudes and perceptions.

Regarding the research questions, the relevant evidence for which comes from the results of the linear regression analyses, education level, gender and, especially, age were found to predict both Fiuman speakers' self-perceived engagement with Fiuman maintenance as well as their attitudes towards and perceptions of it. More specifically, with an increase in education level and, in particular, age, Fiuman speakers' self-perceived engagement with Fiuman maintenance and their positive attitudes towards it rise as well. In addition, Fiuman speakers' positive perceptions of Fiuman maintenance efforts rise with age and they are more characteristic of women than men.

The findings about age are in line with previous studies that describe older generations as custodians of minority languages (Pauwels 2005; Phinney, Romero, Nava and Huang 2001). Their attitudes and transmission efforts are crucial for $\mathrm{LM}$, and it is in home settings that the minority language is passed on to younger generations and positive attitudes towards its use are formed. However, other interlocutors and contexts, such as school, partners, neighbourhood or workplace, become more important and change speakers' attitudes and patterns of language use (cf. Komondouros and McEntee-Atalianis 2007; Soehl 2016). In our context, older speakers belong to the generations when Fiuman was predominantly spoken in both private and public domains and was the first language for most of them. As already noted, Fiuman represents a direct link to their childhood, family and past, but also to Rijeka's history, culture and tradition. Because of limited social contacts outside their families today, they continue using Fiuman within the family, and the majority of them seek to transmit it to younger generations.

Subsequent generations, however, grow up in a different demographic and language setting, where Croatian is dominant, and are raised or educated as bilingual speakers. For them, Croatian and Italian are more important and have greater instrumental, work-related and societal value. Younger speakers frequently attend schools where standard Italian is the medium of instruction, and outside the classroom standard Italian and Croatian are prevailingly spoken. The fact that there is 
an increasing number of students in these schools whose parents and grandparents are not speakers of Fiuman and of those who are not members of the Italian minority in Rijeka does not favour the use of Fiuman in the school context. However, the importance of educational support has been widely recognised in the literature. The educational context could and should, through various activities and programmes in the dialect, contribute to speakers' cognizance of the wider use of Fiuman and the usefulness of knowing it (Cho 2000; Ehala 2009; Gorter and Cenoz 2012; Park and Sarkar 2007; Sofu 2009). Although it has been stated that institutional support has to be accompanied by positive attitudes in order to be efficient (Ehala 2009; Pauwels 2005; Yağmur 2004), it seems fair to say that the presence of Fiuman in school might add to the development of favourable attitudes, especially among younger speakers. Identity issues should also be taken into account when interpreting the findings about age. For many communities, language is a core value (Smolicz 1980) and closely related to their identity (Komondourous and McEntee-Atalianis 2008; Yağmur and Akinci 2003). Indeed, previous studies on Fiuman show that language, nationality and identity are highly interrelated (Crnić Novosel and Spicijarić Paškvan 2014, 2015; Spicijarić Paškvan and Crnić Novosel 2014). Not having fully developed their identity yet, the youngest Fiuman speakers might be reluctant to use and express inclination towards their minority language in an effort to integrate better into broader community (cf. Luo and Wiseman 2000; Zhang and Slaughter-Defoe 2009).

As for education level, the findings suggest that with a higher education level come the need for a more active involvement in LM and more positive attitudes towards one's strivings to safeguard their own minority language, which is partially in line with the findings of Portes and Hao (2002), Sofu (2009) and Soehl (2016). It seems that more educated Fiuman speakers are more likely to recognise the importance of their dialect and its distinctive role in comparison with Croatian and Italian. While Croatian is the official language in Rijeka, and Italian the official language of Italian minority institutions, Fiuman is perceived as a treasure to cherish because of its historical importance and symbolic value. Additionally, most of them are multilingual speakers and aware of the value of their multilingual repertoire.

Regarding gender, the finding that women perceive Fiuman maintenance efforts more positively than men is not surprising given that gender has long been recognised to affect LM efforts. More precisely, previous studies revealed that women are more likely to transmit the minority language to their children (Clyne and Kipp 1997; Romaine 1995), and that they encourage its use and value its social and affective functions more positively than men (Holmes 1993; Winter and Pauwels 2005). The findings of our study are consistent with this.

Despite being grounded primarily in speakers' attitudes and perceptions in relation to Fiuman maintenance, and not in their actual use of Fiuman, the findings of this study extend the knowledge of the present-day status of Fiuman in regard to LM and LS and confirm some of the previous findings. Specifically, both Plešković, 
Kraš and Drljača Margić (2019) and Plešković, Drljača Margić and Kraš (submitted) reveal LM and LS tendencies. In this study, the former are suggested by the fact that Fiuman speakers perceive their engagement with Fiuman maintenance as relatively high, have very positive attitudes towards it and perceive Fiuman maintenance efforts rather favourably. Such findings are in line with the results of Crnić Novosel and Spicijarić Paškvan (2014, 2015), Spicijarić Paškvan and Crnić Novosel (2014) and Plešković, Drljača Margić and Kraš (submitted), which report great speakers' emotional attachment to Fiuman as a symbol of minority identity and Rijeka's heritage. What indicates possible LS is the fact that speakers perceive their dialect as endangered (despite their declared efforts), which is what Lukežić (1993), Rošić (2002) and Plešković (2019) also argue. The second indicator of LS is the fact that speakers' self-perceived engagement with and positive attitudes towards Fiuman maintenance increase with their age.

Based on our findings, some recommendations for improving the prospects of Fiuman maintenance can be given. Given that age and education level are significant predictors of Fiuman speakers' self-perceived engagement with and attitudes towards Fiuman maintenance, more effort should be put into raising awareness of the importance of Fiuman maintenance among younger Fiuman speakers, as well as into encouraging multilingualism and the appreciation of minority languages and cultures, and linguistic and cultural diversity in general, from the earliest age and lowest education level. Institutions relevant to the Fiuman community, such as nurseries, schools, theatres and the media, should continuously develop and/or offer content and organise activities related to Fiuman, and find ways to involve all community members.

\section{Conclusion}

This questionnaire-based study revealed that age and, to a lesser extent, gender and education level and gender, predicted Fiuman speakers' self-perceived engagement with, attitudes towards and perceptions of Fiuman maintenance. A positive association was found between age and education level and speakers' selfperceived engagement with and attitudes towards Fiuman maintenance, as well as between age and gender and speakers' perceptions of Fiuman maintenance efforts, suggesting that all of these variables increase in the same direction and that women have more positive perceptions of Fiuman maintenance efforts than men. We interpret these findings as indicative of both LM and LS tendencies.

The findings of the study, which, unlike previous studies on Fiuman, explored Fiuman speakers' attitudes towards and perceptions of Fiuman maintenance in relation to their age, gender and education level, open up avenues for further enquiry into the maintenance of Fiuman. The quantitative data analysed in the study, obtained via a questionnaire, should be complemented by data obtained via more qualitative methods, such as interviews, as this would provide a deeper insight 
into the impact of age, gender, education level on Fiuman speakers' attitudes and perceptions in relation to Fiuman maintenance. The qualitative approach to the investigation of other aspects of Fiuman maintenance has already been taken in Plešković (2019) and Plešković, Drljača Margić and Kraš (submitted). An ethnographic approach would also be highly revealing. Data should also be collected from the representatives of the minority institutions as well as the city administration, as their attitudes and perceptions might shed additional light on Fiuman maintenance (efforts).

Given the importance of looking into the actual language use, choices and preferences of minority language speakers for studying LM and LS, the findings of this study should be considered in combination with the findings of Plešković, Kraš and Drljača Margić (2019) and Plešković (2019) in order to make bolder statements about the degree of Fiuman endangerment and the prospects of its maintenance. Additional studies exploring the use of Fiuman in different domains are also encouraged. Further research is also needed to uncover whether age, gender and education level have an impact on actual use of Fiuman in different domains, and not only on speakers' attitudes and perceptions in relation to its maintenance. The role of other individual factors, such as social class and ethnicity, should also be examined. Finally, future studies should explore to what extent the results of our study can be generalised to other regional minority communities.

\section{Acknowledgements}

The research leading to these results has received funding from the European Union's Seventh Framework Programme for Research, Technological Development and Demonstration under grant agreement No. 613465. The work of doctoral student Maša Plešković has been supported in part by the Croatian Science Foundation. We thank Igor Kardum for his generous help with the statistical analysis.

\section{References}

Badurina, Lada, and Mihaela Matešić (2008). Riječka jezična zbilja: Urbani govor između sustava i standard [Language situation in Rijeka: Urban speech between language system and standard language]. Sveti Vid, ZbornikXIII(1): 111-120

Bató, Maria (1999). Fijumanski dijalekt [The Fiuman dialect] (Lavinia Belušić, Trans.). Lukežić, Iva, ed., Fijumanski idiom: Zbornik tekstova. Rijeka: Izdavački centar Rijeka, 50-86

Berghoffer, Giuseppe (1999). Prinosi proučavanju fijumanskoga dijalekta (gramatička rasprava) [Contributions to the study of the Fiuman dialect (a discussion on grammar)] (Iva Lukežić, Trans.). Lukežić, Iva, ed., Fijumanski idiom: Zborniktekstova. Rijeka: Izdavački centar Rijeka, 7-35

Bidwell, Charles (1967). Colonial Venetian and Serbo-Croatian in the Eastern Adriatic: A case study of languages in contact. General Linguistics 7(1): 13-30 
Blecich, Kristina, and Sanda Tamaro (2015). Voci di origine romanza, slava e germanica nella terminologia gastronomica e culinaria del dialetto fiumano. Tabula 13(2): 61-79, https://doi.org/10.32728/tab.13.2.2015.05

Bratulić, Ana, Branka Drljača Margić, and Tihana Kraš (2017). Upitnik o fijumanskom dijalektu [The Fiuman dialect questionnaire]. [Questionnaire]. Unpublished instrument. Accessed 15 January 2018, http://bmri.uniri.hr/bmr/wp-content/uploads/2018/05/ Upitnik-o-fijumanskom-dijalektu.pdf

Bratulić, Ana, Maja Đurđulov, Kristina Blecich, and Tihana Kraš (2015). The Fiuman dialect. State of the art report on grammatical diversity of regional languages, 145-165. Accessed 15 January 2018, http://www.atheme.eu/wp-content/uploads/2016/04/D2.2State-of-the-art-report-on-grammatical-diversity-of-regional-languages-2.pdf

Callan, Victor J., Cynthia Gallois, and Paula Forbes (1983). Evaluative reactions to accented English: Ethnicity, sex role and context. Journal of Cross-Cultural Psychology 14(4): 407-426, https://doi.org/10.1177/0022002183014004002

Cavanaugh, Jillian R. (2006). Little women and vital champions: Gendered language shift in a northern Italian town. Journal of Linguistic Anthropology 16(2): 194-210, https://doi.org/10.1525/jlin.2006.16.2.194

Cho, Grace (2000). The role of heritage language in social interactions and relationships: Reflection from a language minority group. Bilingual Research Journal 24(4): 333-348, https://doi.org/10.1080/15235882.2000.10162773

Clyne, Michael, and Sandra Kipp (1997). Trends and changes in home language use and shift in Australia, 1986-1996. Journal of Multilingual and Multicultural Development 18(6): 451-473, https://doi.org/10.1080/01434639708666334

Crnić Novosel, Mirjana, and Nina Spicijarić Paškvan (2014). Fijumani i stavovi o fijumanskom idiomu u 21. stoljeću [Fiumans and their attitude towards the Fiuman dialect in 21st century]. Stolac, Diana (ed). Riječki filološki dani 9. Rijeka: University of Rijeka, Faculty of Humanities and Social Sciences, 409-419

Crnić Novosel, Mirjana, and Nina Spicijarić Paškvan (2015). Il dialetto fiumano - parte integrante dell'identità fiumana [Fiuman dialect - integral part of identity of Rijeka]. La Battana 51(198): 62-83

Croatian Bureau of Statistics (2001). Census of population, households and dwellings 2001. Accessed 15 January 2018, https://www.dzs.hr/Eng/censuses/Census2001/ census.htm

Croatian Bureau of Statistics (2011). Census of population, households and dwellings 2011. Accessed 15 January 2018, https://www.dzs.hr/default_e.htm

Depoli, Attilio (1913). Il dialetto fiumano: Saggio grammaticale [The Fiuman dialect: A grammatical treatise]. Bullettino della Deputazione fiumana di storia patria 3: 258-315

Depoli, Guido (1999). O fijumanskom dijalektu [On the Fiuman dialect]. Lukežić, Iva (ed.). Fijumanski idiom: Zbornik tekstova. Rijeka: Izdavački centar Rijeka, 36-49

Drljača Margić, Branka, Tihana Kraš, and Siniša Smiljanić (2015). The Fiuman dialect. State of the art report on maintenance of regional languages, 14-18. Accessed 15 January 2018, http://www.atheme.eu/wp-content/uploads/2017/01/D2.1-State-of-the-art-report-on-maintenance-of-regional-bilingualism-version-1.2.pdf 
Ehala, Martin (2009). Ethnolinguisitc vitality and minority education. Journal of Linguistic and Intercultural Education 2(1): 37-48, https://doi.org/10.29302/jolie.2009.2.1.3

Fishman, Joshua A. (1991). Reversing language shift: Theory and practice of assistance to threatened languages. Clevedon, UK: Multilingual Matters

Fishman, Joshua A. (2013). Language maintenance, language shift, and reversing language shift. Bhatia, Tej K. and William C. Ritchie, eds., The handbook of bilingualism and multilingualism. Oxford: Wiley-Blackwell, 466-494, https://doi.org/10.1002/9781118332382.ch19

Folena, Gianfranco (1968-1970). Introduzione al veneziano "de là da mar" [Introduction to the "de là da mar" Vednetian]. Bollettino dell'Atlante Linguistico Mediterraneo 10-12: 331-376

Giles, Howard, Richard Y. Bourhis, and Donald M. Taylor. (1977). Towards a theory of language in ethnic group relations. Giles, Howard, eds. Language, ethnicity, and intergroup relations. London: Academic Press, 307-348

Giles, Howard, and Patricia Johnson (1987). Ethnolinguistic identity theory: A social psychological approach to language maintenance. International Journal of the Sociology of Language 68: 69-99, https://doi.org/10.1515/ijsl.1987.68.69

Giuricin, Luciano, and Giacomo Scotti (2006). Una storia tormentata (1946-1991) [A tormented history (1946-1991)]. Superina, Agnese, ed. Italiani a Fiume 1946-2006. Rijeka: Comunità degli Italiani di Fiume, 15-103

Gorter, Durk, and Jasone Cenoz (2012). Regional minorities, education and language revitalization. Martin-Jones, Marilyn, Adrian Blackledge, and Angela Creese, eds. The Routledge handbook of multilingualism. New York: Routledge, 184-198, https://doi.org/10.4324/9780203154427

Gottardi, Francesco (2007). Come parlavamo [How we used to speak]. Roma: Società di Studi Fiumani

Guardado, Martin (2002). Loss and maintenance of first language skills: Case studies of Hispanic families in Vancouver. The Canadian Modern Language Review/la Revue canadienne des langues vivantes 58(3): 341-363, https://doi.org/10.3138/cmlr.58.3.341

Holmes, Janet (1993). Immigrant women and language maintenance in Australia and New Zealand. International Journal of Applied Linguistics 3(2): 159-179, https://doi.org/10.1111/j.1473-4192.1993.tb00048.x

Jagodić, Devan (2011). Between language maintenance and language shift: The Slovenian community in Italy today and tomorrow. ESUKA - JEFUL 2-1: 195-213

Komondouros, Markos, and Lisa McEntee-Atalianis (2007). Language attitudes, shift and the ethnolinguistic vitality of the Greek orthodox community in Istanbul. Journal of Multilingual and Multicultural Development 28(5): 365-384, https://doi.org/10.2167/ jmmd483.1

Lao, Christy (2004). Parents' attitudes toward Chinese-English bilingual education and Chinese language use. Bilingual Research Journal 28(1): 99-121, https://doi.org/10.1080/15235882.2004.10162614

Lee, Jin Sook (2002). The Korean language in America: The role of cultural identity in heritage language learning. Langauge, Culture and Curriculum 15(2): 117-133, https://doi.org/10.1080/07908310208666638 
Lukežić, Iva (1993). O dvama riječkim pučkim jezicima [On two vernaculars of Rijeka]. Fluminensia 5(1-2): 25-38

Lukežić, Iva (2008). Današnji riječki govor(i) [Todays' language(s) of Rijeka]. Srdoč-Konestra, Ines and Silvana Vranić, eds. Riječki filološki dani 7. Rijeka: University of Rijeka, Faculty of Humanities and Social Sciences, 443-451

Luo, Shiow-Huey, and Richard L. Wiseman (2000). Ethnic language maintenance among Chinese immigrant children in the United States. International Journal of Intercultural Relations 24(3): 307-324, https://doi.org/10.1016/S0147-1767(00)00003-1

Pafundi, Nicola (2011). Dizionario fiumano-italiano, italiano-fiumano [Fiuman-Italian, Italian-Fiuman dictionary]. Padua: Associazione Libero Comune di Fiume in Esilio

Park, Seong Man, and Sarkar, Mela (2007). Parents' attitudes toward heritage language maintenance for their children and their efforts to help their children maintain the heritage language: A case study of Korean-Canadian immigrants. Language, Culture and Curriculum 20: 223-235, https://doi.org/10.2167/lcc337.0

Pauwels, Anne (2004). Language maintenance. Davies, Alan, and Catherine Elder, eds. The handbook of applied linguistics. Oxford: Blackwell, 719-737, https://doi.org/10.1002/9780470757000.ch29

Pauwels, Anne (2005). Maintaining the community language in Australia: Challenges and roles for families. International Journal of Bilingual Education and Bilingualism 8(2-3): 124-131, https://doi.org/10.1080/13670050508668601

Pauwels, Anne (2016). Language maintenance and shift. Cambridge: Cambridge University Press

Phinney, Jean. S., Irma Romero, Monica Nava, and Dan Huang (2001). The role of language, parents, and peers in ethnic identity among adolescents in immigrant families. Journal of Youth and Adolescence 30(2): 135-153, https://doi.org/10.1023/A:1010389607319

Plešković, Maša (2019). Vitalnost fijumanskoga dijalekta - stanje i perspektive na početku 21. stoljeća [Vitality of the Fiuman dialect - Current situation and perspectives at the beginning of the 21st century]. Unpublished doctoral dissertation, University of Zagreb, Zagreb

Plešković, Maša, Tihana Kraš, and Branka Drljača Margić (2019). Changes in the self-reported frequency of use of the Fiuman dialect: Implications for language maintenance. Govor 36(2): 195-218, https://doi.org/10.22210/govor.2019.36.10

Plešković, Maša, Branka Drljača Margić, and Tihana Kraš (submitted). “Ja sam fijumanski dijalekt": očuvanje fijumanskoga dijalekta kroz prizmu stavova $i$ iskustava njegovih govornika ["I am the Fiuman dialect": The maintenance of the Fiuman dialect through the prism of its speakers' attitudes and experiences]. Manuscript submitted for review

Portes, Alejandro, and Lingxin Hao (2002). The price of uniformity: Language, family and personality adjustment in the immigrant second generation. Ethnic and Racial Studies 25: 889-912, https://doi.org/10.1080/0141987022000009368

Portes, Alejandro, and Rubén G. Rumbaut (1996). Immigrant America: A portrait. Berkeley: University of California Press

Potowski, Kim (2013). Language maintenance and shift. Bayley, Robert, Richard Cameron and Ceil Lucas, eds. The Oxford handbook of sociolinguisitcs. New York: Oxford University Press, 321-339, https://doi.org/10.1093/oxfordhb/9780199744084.013.0016 
Romaine, Suzanne (1995). Bilingualism. Oxford: Blackwell

Rošić, Đurđa B. (2002). Linguistic identity of the dialect of Fiume. Unpublished doctoral dissertation, University of Toronto, Toronto

Samani, Salvatore (2007). Dizionario del dialetto fiumano (3 volumes) [The Fiuman dialect dictionary]. Roma: Società di Studi Fiumani

Smith, Benjamin K., Martin Ehala, and Howard Giles (2017). Vitality theory. Oxford Research Encyclopedia of Communication, https://doi.org/10.1093/acrefore/9780190228613.013.496. Accessed 15 January 2018, https://oxfordre.com/communication/view/10.1093/acrefore /9780190228613.001.0001/acrefore-9780190228613-e-496

Smolicz, Jerzy (1980). Language as a core value of culture. Journal of Applied Linguistics 11(1): 1-13, https://doi.org/10.1177/003368828001100101

Soehl, Thomas (2016). But do they speak it? The intergenerational transmission of homecountry language in migrant families in France. Journal of Ethnic and Migration Studies 42(9): 1513-1535, https://doi.org/10.1080/1369183X.2015.1126171

Sofu, Hatice (2009). Language shift or maintenance within three generations: Examples from three Turkish-Arabic speaking families. International Journal of Multilingalism 6(3): 246-257, https://doi.org/10.1080/14790710902878684

Spicijarić Paškvan, Nina (2018). Nazivi slastica u fijumanskom idiomu [Dessert names in the Fiuman dialect]. Fluminensia 30(2): 45-61, https://doi.org/10.31820/f.30.2.11

Spicijarić Paškvan, Nina, and Mirjana Crnić Novosel (2014). Il dialetto fiumano all'inizio del XXI secolo [The Fiuman dialect at the beginning of the 21st centiry]. Rivista italiana di dialettologia: Lingue dialetti società 38: $57-73$

Statut Grada Rijeke [Statute of the city of Rijeka] (2016). Accessed 25 April 2018, http://sn.rijeka.hr/wp-content/uploads/2016/05/Statut-Grada-Rijekepro\%C4\%8Di\%C5\%A1\%C4\%87eni-tekst.pdf

Šimičić, Lucija, and Klara Bilić Meštrić (2018). Arbanaški na raskrižju: Vitalitet i održivost jednog manjinskog jezika [Arbanasi at the crossroads: Vitality and sustainability of a minority language]. Zagreb: Srednja Europa

The Constitution of the Republic of Croatia (2014). Accessed 15 January 2018, https://www. usud.hr/en/the-constitution

Winter, Joanne, and Anne Pauwels (2005). Gender in the construction and transmission of ethnolinguisticidentities andlanguagemaintenanceinimmigrantAustralia.Australian Journal of Linguistics 25(1): 153-168, https://doi.org/10.1080/07268600500113708

Yağmur, Kutlay (2004). Language maintenance patterns of Turkish immigrant communities in Australia and western Europe: The impact of majority attitudes and ethnolinguistic vitality perceptions. International Journal of the Sociology of Language 165: 121-142, https://doi.org/10.1515/ijsl.2004.001

Yağmur, Kutlay, and Mehmet Akinci (2003). Language use, choice, maintenance, and ethnoliguistic vitality of Turkish speakers in France: Intergenerational differences. International Journal of the Sociology of Language 164: 107-128,

https://doi.org/10.1515/ijsl.2003.050 
Zhang, Donghui, and Diana T. Slaughter-Defoe (2009). Language attitudes and heritage language maintenance among Chinese immigrant families in the USA. Language, Culture and Curriculum 22(2): 77-93, https://doi.org/10.1080/07908310902935940

Žerjavić, Vladimir (1993). Doseljavanja i iseljavanja s područja Istre, Rijeke i Zadra u razdoblju 1910-1971 [Immigration and emigration from the Istria, Rijeka and Zadar areas in the period from 1910 to 1971]. Društvena istraživanja: časopis za opća društvena pitanja 2(4-5): 631-656

\section{Stavovi i percepcije govornika u vezi s očuvanjem fijumanskoga dijalekta}

U radu su predstavljeni rezultati istraživanja stavova i percepcija govornikā fijumanskoga o očuvanju toga dijalekta - autohtonoga manjinskog romanskog idioma kojim se govori u Rijeci i okolici. Posebna je pozornost usmjerena dobi, spolu i stupnju obrazovanja govornikā kao individualnim čimbenicima koji mogu utjecati na očuvanje ili napuštanje jezika. Očuvanje jezika odnosi se na situacije u kojima se manjinski jezik rabi u nekim ili svim životnim domenama, dok sve češća uporaba dominantnoga ili većinskoga jezika nauštrb manjinskoga vodi do njegova napuštanja (Pauwels 2004). Kao mjerni instrument poslužio je upitnik kojim su se ispitivali stavovi i percepcije o fijumanskome te jezična biografija i razina poznavanja fijumanskoga govornikā različite dobi, spola i stupnja obrazovanja. Rezultati pokazuju da su dob i u manjoj mjeri spol i stupanj obrazovanja prediktori samoiskazane uključenosti govornikā fijumanskoga u njegovo očuvanje, njihovih stavova prema očuvanju te percepcija očuvanja. Drugim riječima, pokazalo se da samoiskazana uključenost govornikā fijumanskoga u očuvanje toga dijalekta i njihovi pozitivni stavovi prema tome rastu s dobi i višim stupnjem obrazovanja. S porastom dobi rastu i pozitivne percepcije napora koji se ulažu u očuvanje fijumanskoga te su te percepcije izraženije kod žena nego kod muškaraca. Rezultati istraživanja daju uvid u trenutni položaj fijumanskoga dijalekta, onako kako ga vide njegovi govornici, te upućujuistovremeno na tendenciju očuvanjajezikaitendencijunjegova napuštanja. Očuvanjufijumanskoga doprinijelo bi podizanje svijesti o važnosti njegova očuvanja, višejezičnosti, njegovanja manjinskih kultura i jezika te jezične i kulturalne raznolikosti općenito, i to od najranije dobi i najniže razine obrazovanja. Institucije talijanske nacionalne manjine u Rijeci, kao što su vrtići, škole, kazalište i mediji, trebale bi kontinuirano nuditi sadržaje i aktivnosti na fijumanskome i u njih uključivati sve članove zajednice.

Keywords: Fiuman dialect, attitudes, perceptions, language maintenance, language shift Ključne riječi: fijumanski dijalekt, stavovi, percepcije, očuvanje jezika, napuštanje jezika 